\title{
Mikhail Lifshits: an enigmatic Marxist
}

\author{
Andrey Maidansky ${ }^{1} \cdot$ Vesa Oittinen $^{1}$
}

Published online: 16 November 2016

(C) Springer Science+Business Media Dordrecht 2016

Mikhail Lifshits (Lifschitz, Аифшиц, 1905-1983), the Soviet friend and comradein-arms of Georg Lukács has for a long time been a neglected figure, remembered in the West mainly for his work The Philosophy of Art of Karl Marx. The English translation of the book was published in 1938. Although it was republished in the 70s with a short but approving foreword by the distinguished English Marxist Terry Eagleton, Lifshits has remained something of a private tip for the few initiated. ${ }^{1}$ As late as 1997, Stanley Mitchell, who published - at the request of Lifshits' widow, Lidia Reingardt-in the Oxford Art Journal a long essay on Lifshits' views on aesthetics and philosophy, repeatedly pondered the question "why is he not known here"(Mitchell 1997, 38). The situation quite obviously puzzled Mitchell, since, given Lifshits' original interpretation of Marxism, he should have been much more well-known and esteemed not only in Russia, but elsewhere in the world. But no: while Lukács was able to enjoy worldly fame, Lifshits remained in oblivion.

In recent times, however, some changes in this situation are discernible, albeit mostly in Russia only. It is probably too ambitious to speak of a Lifshits renaissance, but nonetheless his disciples and followers have in the last few years, despite financial difficulties and lack of interest on the part of the cultural establishment of present-day Russia, managed to publish new editions of his writings ("writings" is here an

\footnotetext{
1 The first sketch of the book was published already in 1927; the English translation is based on the final version Esteticheskie vzglyady Marksa, published in 1932. A reprint of the English edition by Pluto Press came out in 1973, with a foreword by Terry Eagleton.
}

Vesa Oittinen

vesa.oittinen@helsinki.fi

Andrey Maidansky

maidansky@gmail.com; maid@rambler.ru

$1 \quad$ Helsinki, Finland 
appropriate label, because Lifshits was more an essayist than an academic writer and was not interested in producing large monographs). These publications include even hitherto unknown texts from Lifshits' vast archives, among other things his correspondence with Georg Lukács. Two volumes, consisting of Lifshits' correspondence, have been described in a detailed review by Evgeni Pavlov in the latest issue of Historical Materialism (Pavlov 2012, 187-198). ${ }^{2}$ Another interesting publication is the collection Nadoelo, published in 2012. It contains an extensive interview with Lifshits accorded to the Hungarian Marxist László Sziklai in the 1970s, which provides many valuable clues as to Lifshits' views and intentions. Much, however, remains still unpublished. According to his pupil Viktor Arslanov, in the Archives of Russian Academy of Sciences there are some 700 files of notes, sketches, and other materials waiting for publication (Arslanov 2010, 5). At the moment, there is no good survey of the contents of the archives.

Lifshits' book on Marx's aesthetics was indeed a pioneering work. It was written in a constant struggle on two fronts: against "vulgar sociologism," on the one side, and the ultra-leftist Formalist tendencies, on the other. The so-called Plekhanov orthodoxy had reduced the Marxist theory of art to a kind of sociology, and Soviet Marxism in the 1920s mainly restricted itself to interpreting literature and art as phenomena of the "superstructure" reflecting the economic "basis". Against these tendencies, Lifshits set as his task to reconstruct the genuine Marxist aesthetics from disparate statements by Marx and Engels. However, as Terry Eagleton rightly remarks, his aim was not to distill a separate "philosophy of art" from the corpus of the classics of Marxism. Instead, "he sets out to trace some crucial aesthetic themes in Marx's work in terms of their integral relations to the developing totality of his thought". In doing so, Lifshits showed, that far from being only some kind of superstructure arising on the economic basis of society, the aesthetic moment is present at all levels of Marxist theory; in fact, "Marx had a close and continuous engagement in imaginative production" (Eagleton 1973, 8).

In the early 1930s the young Lifshits met Georg Lukács in Moscow, and this inaugurated a period of fruitful collaboration which lasted for several years. Both Lifshits and Lukács contributed on a regular basis to the journal Literaturnyi kritik. Its first editor was the philosopher Pavel Yudin, who had earned his stripes in the ideological campaign against the "Menshevizing Idealism" of the Deborinites a couple of years earlier. Together with Mark Mitin, Yudin has gone into history as Stalin's

\footnotetext{
${ }^{2}$ The reviewed books of Lifshits are Mikhail Lifshits and G. Lukach, Perepiska 1931-1970, M.: Grundrisse 2011, and Pis'ma V. Dostalu, M. Mikhailovu, V. Arslanovu, M.: Grundrisse, 2011. Other recent publications of Lifshits by this small publishing house are Varia, M.: Grundrisse 2010, and Monten'. Vypiski i kommentarii, M.: Grundrisse 2012, the latter containing materials of an unrealised book project on Montaigne. Further publications: Problema Dostoevskogo (Razgovor s chërtom), M.: Akademicheskii Proekt 2013, and Pochemu ja ne modernist? Filosofija. Estetika. Khudozhestvennaja kritika, M: Iskusstvo - XX vek 2009. Several years earlier - by the financial support of the Aleksanteri Institute in Helsinkiwas published Dialog s Evaldom Ilyenkovym, M: Progress-Traditsija 2003, which is a critical essay on the philosophical ideas of Ilyenkov, especially the concept of the "ideal", and Chto takoe klassika? M: Iskusstvo XXI vek 2004, a collection of fragments from the extensive Lifshits Nachlass by Viktor Arslanov. Finally, one should mention the volume on Lifshits, edited by Viktor Arslanov, which has been published in the series "Russian Philosophy of the Second Half of the twentieth Century" (V. G. Arslanov (ed.). Mikhail Aleksandrovich Lifshits, M: ROSSPEN 2010), containing i.a. a useful bibliography.
} 
henchman in philosophy. The journal did not, however, directly continue this campaign but represented a position Lifshits later called — with an ironical point—-the "Techenie" (Current). Although Deborin had been denounced as a Hegelian, Lukács and Lifshits developed a Marxist theory of art leaning even more on Hegel than Deborin had.

In the works of the Berlin master thinker Lifshits sought a "historical dialectics", the existence of which other Soviet philosophers had not noted (and in the West, too, it was just beginning to come into fashion thanks to the lectures of Alexandre Kojève in Paris). Much as Lenin "consulted Hegel" before taking important political decisions in the years of the First World War and War Communism, so, too, does Lifshits hope that it is possible to understand the logic of the post-revolutionary development of Soviet culture with Hegel's help. He writes:

The Hegel in the works of Deborin and his school was a scholastic philosopher of minor interest, an abstract thinker [...] Our interest in Hegel was of quite dissimilar character. For us, what was important in the doctrine of the German thinker was its real content and a deeply tragic relationship to the events of the French Revolution and the post-revolutionary epoch. All this had many smiliarities with the problems encountered those who have tried to make sense of the immense historical changes which have taken place in our days (Lifshits 2012, 84).

The mission of the artist was, according to Lifshits, to depict in a veridical manner these dramatic and contradictory changes. Of the novelists of the time, whose production best corresponded to the aesthetic and political programme of the "Techenie", Andrei Platonov was the most important. And in fact Platonov published several articles in the Literaturnyi kritik. However, the journal was closed already in 1940 by a Party decree. This came across as the turning point in Lifshits' career, since thereafter he found himself in growing isolation. As Mitchell puts it, "his post-war intellectual role was very different from what it had been in the thirties, particularly when the ideological restrictions were eased after the death of Stalin. Heterodox then, Lifshits now appeared orthodox [...] [H]e was hopelessly isolated from the young, who regarded him as a reactionary" (Mitchell 1997, 34).

Lukács had already aroused opposition among other Marxist theoreticians by stubbornly clinging to the novel of the classical bourgeois epoch as the role model for all subsequent, thus even proletarian, literature and condemning modern art, for example, in the well-known debate on expressionism with Bertolt Brecht. But Lifshits was even more hostile towards new forms of modern art. His essay "Why I am not a modernist?", published in the early $1960 \mathrm{~s}^{3}{ }^{3}$ in which he denounced modernist art as essentially nihilist, sealed his reputation as a retrograde thinker and alienated him from the new generation of the shestidesiatniki, the "liberals" of the Khrushchev era. Solzhenitsyn called him a "fossil Marxist". Lifshits wittily replied: "There are useful fossils, too". The articles written by his critics Lifshits put into a folder labelled "Chorus of the unhatched chickens".

\footnotetext{
3 A German translation of this article was included in the collection of essays: Michail Lifschitz, Krise des Hässlichen, Dresden: Verlag der Kunst 1971.
} 
In the last years of his life Lifshits finally obtained the freedom to write what he thought openly. He was elected corresponding member of the Academy of Arts of the Soviet Union in 1967, his works began to be published, and translations of them appeared in other socialist countries. Lifshits dreamed, alluding to the example of Spinoza, of "presenting a systematic philosophy in a book with the title Aesthetics" (Lifshits 2010, 89). He said:

In a long life so astonishingly little is done, and all that is but spin-offs, occasional works, marginal remarks. Astonishingly little is seen of the invisible part of the iceberg. Indeed, I am myself guilty that this happened (Lifshits 2011, 93).

Following Lifshits' death, a three-volume collection of his works was published (Lifshits 1984-1988) and soon after, in 1987, a German translation of his works, containing texts from the 1930 s, was published in Dresden. ${ }^{4}$ The posthumous publication of Lifshits' manuscript 'Ob ideal'nom i real'nom', which is his critique of Evald Ilyenkov's theory of the ideal, triggered a lively debate that continues to this day.

In his extensive autobiographical interview, published in Hungarian in 1980 and a year later in German with the title Gelebtes Denken, Lukács seems to have taken distance from his erstwhile Russian friend. When the interviewer István Eörsi asked for his views about Lifshits, Lukács answered first with praise:

[W] e were the first to speak about a specifically Marxist aesthetics, not of this or that aesthetics that would complete the systemof Marx's system. The idea that aesthetics forms an organic part of Marx's system is to be found in my article that I wrote about the Sickingen debate between Marx and Lassalle, and in Lifshits this idea is in his early book that he wrote about the young Marx [...] My opinion of Lifshits is that he belonged to the greatest talents living in those times [in the 1930s-A.M. \& V.O.], especially at the purely literary level. He saw the problem of realism very clearly (Lukács 1981, 141).

But then Lukács switched to a more critical tone, claiming that Lifshits "did not extend this to other fields of culture", and remained stuck in his old positions of the 1930s, whilst he, Lukács, on the contrary, had already then managed to go further. Lukács claimed that, unlike Lifshits, he was able in his book Der junge Hegel and especially in the Zerstörung der Vernunft, to give an interpretation of Marxist philosophy that abandoned the official line represented by Zhdanov, which reduced modern philosophy entirely to the opposition between materialism and idealism. "Poor Lifshits stayed in Russia. I do not blame him for this. What could he possibly do in Russia? He supported the line that modern literature is not good. His views became outrightly conservative. I will not say that our friendship would have ceased because of that. But of course I have left those things far behind that Lifshits has not managed to settle to this day" (Lukács 1981, 141-2).

\footnotetext{
${ }^{4}$ Michail Lifschitz, Die dreissiger Jahre. Ausgewählte Schriften, Dresden: VEB Kunst (Fundus-Bücherei 113-115), 1987. It seems that the intention was to publish more volumes, but if so, the fall of the Berlin Wall in 1989 nullified these plans.
} 
The belittling tone of Lukács's memoirs reveals a hidden jealousy between the two Marxist savants. It seems that Lifshits never had the opportunity to read Lukács' interview with Eörsi, but despite this he managed to pay back Lukács. Recently, notes have been published, from the folder No. 232 of Lifshits' archive, labelled simply as 'Lukács', in which he comments, polemically and in a uncompromising manner which was characteristic of him, his friend's writings (see Lifshits 2004, 99-166). Lifshits compared himself to the teacher of swordplay who taught Cyrano de Bergerac some tricks of how to use the saber, but remained in the shadow of his more famous pupil:

But in not one of my main ideas do I see any influence of Lukács. On the contrary, he followed me in at least two major points of his aesthetics [...]: a) the contradiction between capitalism and the destiny of art; b) the idea of realism in the broad sense of the word, or of truth in art (Lifshits 2004, 160).

Acerbically, Lifshits recalled that Lukács had celebrated, in his well-known book Zerstörung der Vernunft, the charlatan of science Lysenko, comparing his position to that of Tertullian's credo quia absurdum (Lifshits 2004, 102). ${ }^{5}$ Although the notes in the folder are very fragmentary, even cryptic, one main line of Lifshits' critique seems to be that Lukács has a tendency to emphasize the role of the subjective factor, whilst Lifshits tends towards a more "Platonic" worldview. Lifshits traces this "subjectivism" in Lukács to a Neo-Kantian influence: "Lukács is insufficiently Hegelian. That he would be a Hegelian is but a fancy. The southwest German current of Neo-Kantianism has had much influence on him much" (ibid., 113). Lifshits followed Lukács's later career and was especially critical of his "ontological turn" in the 1960s. According to him, with the ontology project Lukacs returned to the themes of his youth (ibid. 111). Especially the core idea of the project, the teleology of human activity, was to Lifshits' mind one-sided. Human labour, argued Lifshits, consists not only in the realisation of goals, but is "a reaction that is transformed into the reproduction of life, which generates even the goal itself' (Ibid., 139). In other words, Lukács's concept of human labour is for Lifshits too subjectivistic, since it reduces labour to teleological positing.

Lifshits returned several times to the theme of non finito, the tragic incompleteness of human works, the unfinished solutions of "historical theorems". He referred in this respect, inter alia, to Marx, who, as well, never completed his main work (Lifshits 1985, 190-200). However, he expressed the hope that maybe someone in posterity will be able to reconstruct the "antediluvian animal" from one vertebra of his skeleton. If this indeed is the case, maybe our present thematic issue will prove helpful to the "future Cuvier".

To sum up, there seemed to be something enigmatic in Lifshits' position: clearly he was not a Stalinist, nor an anti-Hegelian, although he opposed the Deborin school. But neither did he belong to the adherents of new and critical trends in Marxism. He did not want to make compromises in his critique of modernism, although nor did he identify with the official doctrine of Socialist Realism. Lifshits characterized himself as chelovek tridtsatykh godov, "a man of the Thirties",

\footnotetext{
${ }_{5}^{5}$ Lifshits adds: "But do you think that Tertullian was a fool because he believed in the absurd?"
} 
pointing to the fact that the early years of the 1930s had been of formative significance for him: all the central motives of his later writings can be traced back to the discussions of this period.

This issue of SEET contains 8 articles that approach the "Lifshits phenomen" from different angles. We begin with an interview by Dmitri Gutov, an internationally known Russian artist, who has devoted much time to researching the Lifshits' heritage and is one of the most important connoisseurs of his work in present-day Russia. The papers by Klimova, Jubara, Maidansky, Oittinen, Dmitriev, Mareev, and Mareeva each deal with certain aspects of Lifshits' oeuvre.

\section{References}

Arslanov, V. G. (2010). Ot redaktora. In V. G. Arslanov, (Ed.), Mikhail Aleksandrovich Lifshits. M: ROSSPEN.

Eagleton, T. (1973). Preface. In M. Lifshitz (Ed.), The philosophy of art of Karl Marx. London: Pluto Press.

Lifshits, M. (1984-1988). Izbrannoe, 1-3, M: Izobrazitel'noe iskusstvo, 1984-1988.

Lifshits, M. (1985). V mire estetiki. M: Izobrazitel'noe iskusstvo.

Lifshits, M. (2004). Chto takoe klassika? M: Iskusstvo XXI vek.

Lifshits, M. (2010). Varia. M.: Grundrisse.

Lifshits, M. (2011). Pis'ma V. Dostalu, M. Mikhailovu, V. Arslanovu. M.: Grundrisse.

Lifshits, M. (2012). Nadoelo. V zashchitu obyknovennogo marksizma. M: Iskusstvo-XX vek 2012.

Lukács, G. (1981). Gelebtes Denken. Eine Autobiographie im Dialog, ed. by István Eörsi, Frankfurt am Main: Suhrkamp 1981 (edition suhrkamp NF 88), p. 141.

Mitchell, S. (1997). Mikhail Alexandrovich Lifshits (1905-1983). Oxford Art Journal, 20(2).

Pavlov, E. V. (2012), [Review of: Perepiska [Letters], Mikhail Lifschitz and György Lukács, Moscow: Grundrisse, 2011; Pisma V. Dostalu, V. Arslanovu, M. Mikhailovu [Letters to V. Dostal, V. Arslanov, M. Mikhailov], Mikhail Lifschitz, Moscow: Grundrisse, 2011] in: Historical Materialism No. 4 (2012), pp. 187-198. 